\title{
Inefficiencies of Basis Swaps to Hedge Foreign Exchange Risk
}

\author{
Camilo Sarmiento* \\ Inter-American Development Bank, Washington, DC, U.S.A
}

*Corresponding Author: Camilo Sarmiento, Inter-American Development Bank, Washington, DC, U.S.A

\begin{abstract}
We find that a cross currency basis swap between the U.S. and emerging economies should not be interpreted as a currency hedge, as the exchange rate risk associated with these transactions is quite high. These risks are significantly lower for a basis swap between the U.S. Libor and Euro Libor. Overall, the use of a cross-currency basis swap requires an assessment of the expected trajectories of exchange rates and the associated risks. Offshore funding is thus an imperfect substitute for onshore funding of operations in a local currency.
\end{abstract}

Keywords: Cross Currency Basis Swap, Hedging, Offshore Funding, Interest Rate Parity.

\section{INTRODUCTION}

Debt issuances in a local currency provide multinational corporations with a mechanism to both hedge for currency risk and, in some instances, conduct risk transfers. For example, if a multilateral organization issues debt in the same local currency than it lends, it then shifts exchange rate risks away from the borrower. Interest rates in local currency incorporate a premium to compensate for this risk. Similarly, multinational organizations prefer in some instances to carry transactions in the local currency of the subsidiary. More generally, non-US banks have a significant loan portfolio in dollar denominated currency.

Governments, however, limit the flow of funds into and out of a country. Indeed, only corporations or financial institutions that have local legal entities can issue onshore funding. This precludes many investors from onshore funding in local currency. Offshore funding is thus the most common mechanism used by multilateral banks, investors, and financial institutions to issue debt in a local currency. Offshore funding generally consists of a cross-currency basis swap.

Cross-currency swaps are interest rate derivatives that represent one of the most liquid benchmarks in the financial service industry. Exchange rate forward contracts are short term currency swaps with a maturity of one-year or less. In a forward contract, the exchange rate is fixed and, therefore, currency movements do not affect cash flows. In contrast, cross currency basis swaps are contracts with maturities that can extend across different maturities and can span from 5 to 10 years. A basis swap does not fix the exchange rate, but rather prices a spread (that is fixed at the inception of the contract) for the cross-currency interest rate swap.

Different from onshore funding, offshore funding requires a currency convertibility at the end of the contract. This implies that onshore funding is a preferable alternative for funding operations in local currency. However, we show in the paper that offshore funding embeds no currency risk if the uncovered interest rate parity model holds.

This paper starts with a description of the assumptions that underlie a cross currency basis swap between a Colombian counterparty and a U.S. counterparty. The paper then tackles the misconception that cross currency basis swaps provide a hedge against currency risk. For example, conditions for which a cross currency basis swap generate a perfect hedge are identified, and the conditions hold only if the uncovered interest parity model holds. In this instance, movements in cross country rates are compensated by exchange rate movements.

The conditions for the uncovered interest rate parity model are then empirically tested, and we find that a cross currency basis swap between the U.S. and emerging economies should not be interpreted as a currency hedge, as the exchange rate risk associated with these transactions is quite high. These risks are significantly lower for a basis swap between the U.S. Libor and Euro Libor. 
Overall, the use of a cross-currency basis swap requires an assessment of misalignments in the trajectories of exchange rates and the associated risks. Offshore funding is thus an imperfect substitute for onshore funding of operations in a local currency.

\section{COST OF FUndS IN A LOCAL CURRENCY}

Governments limit the flow of funds into and out of a country. Indeed, only corporations or financial institutions that have local legal entities can issue onshore funding. This precludes many investors from onshore funding. Offshore funding is thus the most common mechanism used by multilateral banks, investors, and financial institutions to issue debt in a local currency. Offshore funding generally consists of a cross-currency basis swap.

We next illustrate the concept of a cross currency basis swap between U.S Libor rate and Colombia's inter-banking lending rate, referred as IBR.

\subsection{Colombia Cross Currency Basis Swaps}

A cross currency basis swap is an interest rate swap, which generally involves the exchange of two floating rates cash flows. The interest rate is exchanged on a notional amount. A cross currency swap in addition to being floating to floating swap, is also a swap where two parties can swap one currency to another.

The swap is quoted in basis points over different contract periods. During the contract term, the U.S. counterparty receives IBR $+\alpha$ (where $\alpha=$ spread) and pays 3M Libor. The counterparty pays Libor.

At expiration of the contract the principals in the swap are exchanged again. The exchange occurs at prevailing exchange rates. Therefore, if following the start of the contract the local currency drops (gains) in value then the U.S. counterparty receives a higher (lower) principal in U.S. Libor at the end of the contract.

Overall, the cost of funds of a U.S. institution associated with a cross currency swap from U.S. dollars to Colombian pesos is:

Cost of Funds $s_{t, M}=\frac{I B R_{t, M}+\alpha_{t, M}}{C F X(t)}+$ Funding Margin ${ }_{t}$.

where

$\alpha_{t, M}=$ Spread over IBR on an M-year contract; and

$C F X(t)=$ Cumulative change in the exchange rate from U.S. dollar to Colombian peso from the start of the cross-currency swaps contract.

While the swap pertains to a floating to floating rate swap, the spread, $\alpha$, hinges on economic conditions. For example, a worsening of economic conditions would increase the spread of IBR to Libor as investors fly to safely. This would be associated with an event that was not priced in the spread.

\subsection{Conceptual Formulation of a Cross-Currency Basis Swap}

A cross-currency basis swap provides currency hedges for longterm maturity contracts. It thus complements FX forward contracts that are generally available only for up to a year.

Conceptually, the swap equation of a cross currency basis swap is represented as:

$\prod_{k=t}^{s}[1+f(t, k)] / \prod_{k=t}^{s}\left[1+L(t, k)+\alpha_{s}\right]=\frac{1}{\beta_{s}}$

where

$t=$ Start period of swap;

$f(t, s)=$ Forward IBR rate at time $\mathrm{t}$ for tenor $s$;

$L(t, s)=$ Forward Libor rateat time $\mathrm{t}$ for tenor $s$; and

$\beta_{S}=$ Notional on IBR versus notional on Liborbased on prevailing exchange rate at swap period start.

By definition, the swap spread quote for Libor at tenor $\mathrm{s}$ is: 
$\operatorname{Swap} \operatorname{Libor}(\mathrm{s}, \mathrm{t})=\left\{\prod_{k=t}^{s}[1+L(t, k)]\right\}^{1 /(s-t)}-1-L(t, t){ }^{1}$

The U.S. counterparty incurs a net zero gain in the transaction if the exchange rate of the U.S. dollar to Colombian peso sufficiently change to compensate for movements in $f(t, k)$ and $L(t, s)$.

Therefore, the cross-currency swap in (2) constitutes a perfect hedge to currency risk if the uncovered interest rate parity model holds. That is,

$\frac{E F X(s)}{F X(t)}=\frac{1}{\beta_{s}}=\prod_{k=t}^{S}[1+f(t, k)] / \prod_{k=t}^{s}\left[1+L(t, k)+\alpha_{s}\right]$

where

$\operatorname{EFX}(s)=$ Expected value of exchange rate U.S. dollar to Colombian peso at time s; and

$F X(t)=$ Current exchange rate U.S. dollar to Colombian peso at time $t$.

The uncovered interest rate parity in (4) relates to the capital account and states that if capital flows are free and exchange rates are flexible, the rate of return of a U.S. bond equals the rate return of a comparable foreign bond that is converted into dollars at the end of the contract. That is, any movements in the notional amounts are fully compensated by movements in the respective countries interest rates.

\section{Testing the Uncovered Interest Rate Parity Model}

The theoretical underpinning of the cross-currency basis swap model is the uncovered interest rate model. The model states that the expected change in the exchange rate between countries A and B depends on the difference in interest rate between these two countries.

The economic literature has extensively examined the uncovered interest rate parity model. Among others, Engle (2006), Froot and Thaler (1990), Taylor (1995), Lucio (2005), Chinn (2006), and Isard (2006) indicate that the interest rate differentials are not sufficiently compensated by exchange rate movements.

\subsection{U.S. Dollar Versus Pesos (Colombia)}

We next regress the spread between Colombian IBR rate to the U.S. Libor rates. The testing is obtained by estimating a simple OLS regression of the interest rate differential on the annual change in the exchange rate.

The testing uses the quarterly data on 3-month Libor rate and 3-month IBR rate as well as the exchange rate of U.S. dollar to Colombian pesos. The structure of the test is as follows:

$\frac{F X(t+j)}{F X(t)}=\quad \gamma\left\{\frac{1+3 M \text { IBR Rate }(t)}{1+3 M \text { Libor Rate }(t)}\right\}+e(t)$

where $\mathrm{j}=4$ under quarterly data.

The IRP model holds if $\gamma=1$.

The testing results in Table 1 indicate that for the period 2000 to 2019, the condition that underpins the uncovered interest rate parity model in (4) is strongly rejected for the U.S. dollarversus the Colombian pesos.

Table1. Uncovered Interest Rate Parity Model Test: U.S. vs. Colombia

\begin{tabular}{|c|c|c|c|}
\hline Parameter & Coefficients & Standard Error & $t$ Stat \\
\hline$\gamma$ & 0.26 & 0.03 & 9.57 \\
\hline
\end{tabular}

From the analysis, the cross-currency swap between Libor and IBR is capturing other factors that are different from exchange rate movements. Therefore, the condition in (4) does not hold and the swap

\footnotetext{
${ }^{1}$ The Swap spreads - defined as the difference between the fixed rate paid in a swap contract and the Treasury yield of the same maturity capture the economic price of paying the fixed rate in a swap contract. Due to arbitrage opportunities, the swap rate curve tends to gravitate above to the yield curve. Liquidity is the more important determinant of swap spreads, with credit risk having second-order impacts. The reasoning is that netting and imposing of collateral has essentially removed the risk of default by a counterparty in a swap contract (see Sarmiento, 2020).
} 
is not covering for exchange rate risk, but other factors that are not clearly identified. This implies that a cross currency swap of Libor to IBR leaves both counterparties exposed to exchange rate movements.

The dramatic failure of the uncovered interest rate parity model in relation to the U.S. dollar and the Colombian peso relates partly to foreign currency interventions in Colombia that are fully sterilized. That is, exchange rate movements in Colombia are decoupled from interest rate movement by design of monetary policy. Furthermore, Colombia (as well as Mexico) intervene the exchange rate when it assesses that the currency undervalued (overvalued) while sterilizing these transactions.

\subsection{U.S. Dollar Versus Pesos (Mexico)}

As in Table 1, the testing results in Table 2 indicate that for the period 2000 to 2019, the condition that underpins the uncovered interest rate parity model is strongly rejected for U.S. and Mexico.

Table2. Uncovered Interest Rate Parity Model Test: U.S. vs.Mexico

\begin{tabular}{|c|c|c|c|}
\hline Parameter & Coefficients & Standard Error & $t$ Stat \\
\hline$\gamma$ & 0.31 & 0.01 & 27.81 \\
\hline
\end{tabular}

\subsection{U.S. Dollar Versus Real (Brazil)}

As in Tables 1 and 2, the testing results in Table 3 indicate that for the period 2000 to 2019, the condition that underpins the uncovered interest rate parity model is strongly rejected for U.S. and Brazil.

Table3. Uncovered Interest Rate Parity Model Test: U.S. vs.Brazil

\begin{tabular}{|c|c|c|c|}
\hline Parameter & Coefficients & Standard Error & $t$ Stat \\
\hline$\gamma$ & 0.15 & 0.01 & 20.01 \\
\hline
\end{tabular}

As in the case for Colombia and Mexico, the condition for a perfect hedge in (4) does not hold for Brazil and the U.S.. That is. the cross-currency swap between Libor and Brazil interbank lending rate is not covering for exchange rate risk, but other factors that are not clearly identified.

\subsection{U.S. Dollar Versus Euro}

The large departures from the uncovered interest rate parity model between the U.S. and major Latin American countries partly stems from restriction to capital flows and exchange rate interventions. To underscore this point, we test the parity model between the U.S. Libor and EURO Libor. The testing results in Table 4 indicate that the condition for a perfect hedging in (4) better hold for more similar assets classes. The interest rate parity model is thus a better reflection of reality among more homogenous asset class.

Table4. Testing of Uncovered IRP model for U.S. and Euro in the period 2000 to 2019

\begin{tabular}{|c|c|c|c|}
\hline Parameter & Coefficients & Standard Error & $t$ Stat \\
\hline$\gamma$ & 0.86 & 0.05 & 18.37 \\
\hline
\end{tabular}

\section{CONCLUSION}

A cross currency basis swap is an interest rate swap, which generally involves the exchange of two floating rates cash flows. The interest rate is exchanged on a notional amount. A cross currency swap in addition to being floating to floating swap, is also a swap where two parties can swap one currency to another.

At expiration of the contract the principals in the swap are exchanged again. The exchange occurs at prevailing exchange rates. Therefore, if following the start of the contract the local currency drops (gains) in value then the U.S. counterparty receives a higher (lower) principal in U.S. Libor at the end of the contract. In case of a default of the counterparty, the U.S. counterparty is responsible to paying down the swap in Libor and, thus, incurs a loss only if the value of the local currency drops from the inception of the contract.

The results of the paper indicate that the cross-currency basis spread cannot be interpreted as a protection against exchange rate movements, as the theoretical framework in (4) would suggest. In 
particular, the failure of the interest rate parity model suggests that engagements on cross currency swaps of U.S. Libor against IBR requires a well-defined view on expected exchange rate movements and recognize the risk associated with that view.

Overall, the use of cross-currency basis swap requires an assessment of misalignment in the trajectories of exchange rate and the associated risks, as the currency risk is shifted from the lender to the borrower. The offshore funding is thus an imperfect substitute to onshore funding of operations in a local currency.

\section{REFERENCES}

[1] Chinn, M.D. (2006) "The (partial) rehabilitation of interest rate parity in the floating rate era: Longer horizons, alternative expectations, and emerging markets" Journal of International Money and Finance 25, 7-21.

[2] Engel, C. (2016) "Exchange rates, interest rates, and the risk premium" American Economic Review 106, 436-74.

[3] Froot, K.A., and R.H. Thaler (1990) "Foreign exchange" Journal of Economic Perspectives 4, 179-192.

[4] Lucio, S. (2005) "Viewpoint: Towards a solution to the puzzles in exchange rate economics: Where do we stand?" Canadian Journal of Economics 38, 673-708.

[5] Sarmiento, C. (2020) "Adjusted Forward Curve Model for Spot rate Forecasting" Economics 9, 1-7.

[6] Taylor, M.P. (1995) "The economics of exchange rates" Journal of Economic Literature 33, 13-47.

\section{AUTHOR'S BIOGRAPHY}

Camilo Sarmiento, Ph.D., has expertise in the areas of econometrics, finance, risk modeling, and macroeconomic forecasting. Camilo has published more than 35 articles in peer-referred journals as well as produced over 60 internal technical reports on model testing and development for top financial institutions. He has also worked as an Assistant Professor, Associate Research Scientist, and Consultant for universities and non-profit organizations. In his spare time, Camilo created the blog, Insights on Financial News.

Citation: Camilo Sarmiento. "Inefficiencies of Basis Swaps to Hedge Foreign Exchange Risk" International Journal of Managerial Studies and Research (IJMSR), vol 8, no. 11, 2020, pp. 62-66. doi: https://doi.org/10.20431/2349-0349.0811007.

Copyright: ( $) 2020$ Authors. This is an open-access article distributed under the terms of the Creative Commons Attribution License, which permits unrestricted use, distribution, and reproduction in any medium, provided the original author and source are credited. 